\title{
The Mediating Role of Perceived Organizational Support between Qualitative Job Insecurity, Organizational Citizenship Behavior and Job Performance
}

\section{Khan RU* and Ghufran H}

Department of Business and Management Sciences, International Islamic University, Islamabad, Pakistan

\begin{abstract}
Employees need to security during working environment to perform their job effectively, therefore job insecurity has an effect on organizational citizenship behavior (OCB) and job performance; main purpose of this study is to investigate the mediating role of perceived organizational support, as a process underlying the relationship between qualitative job insecurity, OCB, and job performance. For analysis of correlation and regression we use SPSS software, this study reports the responses of 387 Pakistani employees. Data were collected through a self-report questionnaire that used standard scales on qualitative job insecurity, POS, OCB and job performance. The result of regression shows that effect of job insecurity on OCB and job performance was completely mediated by POS. The research design was crosssectional, and thus, cause-effect relationships cannot be separated. Organizations may address HRM policies to reduce job insecurity (e.g., through actions to organizational communication), and to increase POS (e.g., involving workers in the decision-making process and promoting teamwork). For the first time in a Pakistani context, POS was tested as a mediator in order to explain the relationship between job insecurity, OCB, and job performance.
\end{abstract}

Keywords: Perceived organizational support; Organizational citizenship behavior; Job performance; Qualitative job insecurity; Pakistan

\section{Introduction}

The global financial crisis was started after 2007, every organization gets shocks from this crisis and which goes the organization towards the insecurity and uncertainty problem among employees [1]. After the existence of a global financial crisis, employees start feeling insecurity in organizations. The reasons, management not providing basic needs protection to his employees. Organizations start mergers, acquisitions and different types of management structure changes that produced increase feelings of insecurity and uncertainty among employees [1]. In this case, the employees did not worry about current position, i.e., (quantitative job insecurity), but also losing important aspect related with job characteristics i.e., (qualitative job insecurity). Many past studies the negative impact of quantitative job insecurity on employees' well-being, job attitudes and behaviors [2], research on qualitative job insecurity is less. In very rare case researcher has done research on organizational citizenship behavior and job performance. A few recent studies are showing that there are negative of qualitative job insecurity on OCB and job performance [3], The study aims qualitative job insecurity effect on OCB and job performance in the context of social exchange theory (SET). Furthermore, this study tries to provide a social psychology framework considering the mediating role of perceived organizational support. The general assumption is that employees need to feel secure himself, to perform their job effectively, the job insecurity reduces POS, and POS improve OCB and job performance. Therefore the present study aims to make several important contributions to the qualitative job insecurity literature and its relation to performance as well. First, this study adds to theory building that how qualitative job insecurity has an effect on OCB and job performance. Second, by explaining the mediating role of POS, we test a possible intervening mechanism in order to explain the relationship between qualitative job insecurity and behavioral outcomes. Third, the mediating role of POS between qualitative job insecurity, organizational citizenship behavior, and job performance are empirically unexplored. Therefore, the present study aims to explain the relationship between qualitative job insecurity, organizational citizenship behavior, perceived organization behavior and job performance outcomes.

Organizations suffer from different sort of problems which create the problem of uncertainty and insecurity among the employees. The research on the quantitative job insecurity for employee's wellbeing, health and job behavior has been done in the past papers [2], but research on qualitative job insecurity is nothing. Due to the market competition and increasing cost, the companies trying to revise the structure of organizations. The restructuring and reorganizing phenomena are explored in last twenty years in USA and Europe [4]. The management trying to take care of well-being, health and basic needs against fulfilling the responsibility of providing services to the organization explore in perceived organizational support with discussed by Eisenberger et al. [5]. According to Eisenberger et al. [5], POS present the relationship between employee level of quality and organization. And Perceived organizational support also presenting the concept through which employee believes that management taking cares their well-being and health [6].

Thus, the present study focus on hotel sector in Pakistan, to explore the relationship among Job insecurity, POS, OCB, and job performance. The purposes of this study is (1) examine the effect of qualitative Job insecurity on OCB and job performance; (2) investigate the impact of employee Job insecurity on POS; (3) verify the effect of employee

*Corresponding author: Khan RU, Department of Business and Management Sciences, International Islamic University, Islamabad, Pakistan, Tel: 00923439088900; E-mail: rizwanhayat1989@gmail.com

Recieved February 02, 2018; Accepted March 20, 2018; Published March 28 2018

Citation: Khan RU, Ghufran H (2018) The Mediating Role of Perceived Organizational Support between Qualitative Job Insecurity, Organizational Citizenship Behavior and Job Performance. J Entrepren Organiz Manag 7: 228. doi: 10.4172/2169-026X.1000228

Copyright: $(2018$ Khan RU, et al. This is an open-access article distributed under the terms of the Creative Commons Attribution License, which permits unrestricted use, distribution, and reproduction in any medium, provided the original author and source are credited. 
POS on OCB and job performance; (4) explore the mediating effect of POS between OCB and job performance and of the influence of Job insecurity on job performance.

The past studies have done work on "the mediating role organizational identification in in the relationship between qualitative job insecurity, organizational citizenship behavior, and job performance, But we want to examine the effect of mediating role of perceived organizational support on qualitative job insecurity, $\mathrm{OCB}$, and Job performance, because there are different role and regulation, organizational structure is different in Pakistan from other countries.

\section{Literature Review}

Qualitative job insecurity link with insecurity during a job in future [7] regarding increment, the lake of career opportunities, decreasing salary, development, and training. While increasing competition in the globe, everything is affected by fast technological expansion, recent financial collapse results show that all accidents are appearing due to the job insecurity. Quantitative job insecurity and qualitative job insecurity [8], divide into two different dimensions of job insecurity: quantitative job insecurity, i.e., worrying about losing job itself, it is related to the general and qualitative job insecurity, i.e., worrying about losing important job features.

Organizational support theory expresses that those employees which are a permanent employee of any organization, that is the possibility, that the organization will an incentive on their best performance and help them during any accidents $[5,9,10]$. The employee will be doing hard work and show any positive outcome (profit) to the organization that will create the positive impression from the organization. Whenever any employee receives strong positive support, that positive support establishes the socio-emotional needs, positive job attitudes, including job satisfaction.

Organizational citizenship behavior is the behavior that helps the organization but not directly in the organization's formal reward system [10]. OCB is an employee's natural and further skills that are affected by outside factors from the organization. In the organization, there is the mistreatment behavior customer, and the remaining employees will do directly complaints to the CEO of the organization against the mistreatment behavior of the customer. That employee who is continually repeating the mistreatment behavior is taking significantly negative effect on the other employees in the organization. For example, if one's employer is affected by the mistreatment citizenship behavior, he or she will start the negative performance during the work and show bad performance, not achieving the target and non-cooperation [11]. OCB is a person's professional commitment to an organization or company that is not part of his or her contract tasks.

Job performance may be conceptualized as acts and behaviors individual basis that contribute to acquiring the jobs and organizational goals [12]. This aspect of job Performance is consistent with Organ's conceptualizations of OCBs. In such a case, employee struggle to consume his own energy or stamina for achieving the organizational goals, consequently the employee receives remuneration from the organization. If an employee feels insecure, consequently his performance decreases with the passage of time.

Qualitative job insecurity and behavioral outcomes: job performance and OCB. Past studies results show that there a negative relationship between qualitative job security and OCBs [13]. Feather and Rauter [13] explore the comparison between contract teacher and permanent teacher. Job insecurity has done no effect on contract teacher because he or she is not giving priority to satisfaction but their focus on the job, Contract teacher will perform well instead of giving any security, ego and health care or not. While the permanent teacher is effected from job environment. The past studies have explained the different result of job insecurity and OCB [2]. The employees are feeling insecure toward job for future [14]. If employees felt insecure but unstill they are satisfied from job environment, in that case, the job insecurity has positive relation but it is limited to the part-time employee. From the past studies, we know that job insecurity has a negative relation with OCBs. Therefore we say that there a negative relationship between job insecurity and OCB.

The previous studies show that there a negative relationship between job insecurity and job performance. Firstly, when an organization fails for delivering employees contracts rights (e.g., incentives for best performance), the failure of the organizational contract taking directly effects on the employee mind low trust regarding the organization, and they feeling low job performance $[15,16]$. In one current study investigated that there is a negative relationship between job insecurity and OCB. These results can be explained considering qualitative job insecurity as a hindrance stressor, because workers may perceive no opportunities for growth. Therefore we are explaining that there a negative relationship between job insecurity and job performance, because if the organization is not providing protection against the family, ego, and well-being of employee, then that insecurity directly effects on employee job performance. Job insecurity reflects one's "perceived powerlessness to maintain desired continuity in a threatened job situation" [7]. More simply, insecure employees perceive the threat of losing their job. The job insecurity reflects anticipating the loss of one's job.

As job interference, qualitative job insecurity would affect the achievement of job goals and would reduce positive behaviors towards individuals and organization. On these assumptions, we know that there a negative relationship between qualitative job insecurity and job performance. Therefore, we propose the following hypotheses:

H1: Job security negative related with OCBs.

H2: Job insecurity negative related with Job performance

\section{The mediating role of POS}

This study supporting social exchange theory (SET), perceived organizational support denotes employees' overall career care related to organization values their donation and cares about their well-being [5] The caring agreement involved in perceived organizational support lead employees to focus on psychological needs [17]. The past study evidence shows that POS can lead to employees' towards the commitment of care about organizational objective [17]. Job insecurity is expected that there is a negative relationship with POS. The organization which providing insecurity to his employees, that insecurity directly effects on the employee psychological needs because the employees believe that their organization values their contributions and cares about their wellbeing and fulfills socioemotional needs. If any employee which feels dissatisfaction with organization, it means that employee feeling bereave from rights of working environment which expects from organization like promotion etc. that insecurity of employee are directly effect on employee performance like satisfaction, organizational commitment, various forms of citizenship and discretionary behavior, attendance and intention to stay [17]. More important (SET) and socio-emotional documents outlined above showing the relationship. The employees who feel unsecure about future in the organization. But on the other side those employees which have fully secure about their future results 
Citation: Khan RU, Ghufran H (2018) The Mediating Role of Perceived Organizational Support between Qualitative Job Insecurity, Organizational Citizenship Behavior and Job Performance. J Entrepren Organiz Manag 7: 228. doi: 10.4172/2169-026X.1000228

Page 3 of 7

in the employee be satisfied and encourage toward work. From the past studies, we suggest that there are a negative relationship between qualitative job insecurity and perceived organizational support.

H2: Qualitative job insecurity is negatively related to POS.

\section{Perceived organizational support has positive effect on OCB and job performance}

Based on the social exchange theory, when perceiving organizational support, employees tend to choose organizational citizenship behavior. The characteristics of organizational citizenship behavior are to share knowledge, to create a feeling of obligations to the organization and to provide positive reply because these behaviors are not to allow and organizational citizenship behavior is more likely to represent an exchange relationship between employees and organizations [14]. Employees who are thinking positive about organization those employees will be making possible repay the organization [10]. When employees understand that specific organization is not supporting to employees, results that directly effect on performance due to their thoughts from the organization about socioemotional needs. And when employees are feeling high POS will show positive response and high organizational citizenship behavior toward organizations [17]. The study found that POS has significant positive effects on organizational citizenship behavior [18,19]. Rhoades and Eisenberger [17] Mention that POS carries a positive impact on employee's job performance, such as well performance and providing creative suggestions and helping members $[9,17,20,21]$. Reported that their positive relationships between POS and OCB in their studies Lynch et al. [22] shows that low POS affiliated with employee "reciprocation wariness," which has a negative effect on their job performance. Overall, the [10] metaanalysis suggests that variables relating generally to employee "morale". From the past arguments that there a positive relationship between POS and OCB. Hochwarter et al. [23] currently, explain the relationship between POS and job performance base on past documentary of social exchange theory. The researchers explain the POS term and conditions which are helpful for workers during completing the targets [23]. POS can change the term and condition that is directly effect on the worker's performance at critical incidents signaling from organizational support [24]. High levels of POS showing the positive feelings of responsibility, organizational support, and long-term trying to achieve his goals [17]. Accordingly, in the past studies, the researchers show that through all discrepancies are eliminated through POS and employees shows positive performance [17]. In past studies the empirical studies showing the relationship between POS and JP [25], That is the employee's perception whenever the organization is providing the high level of support are likely showing the high level of job performance. Cropanzano et al. [26], Nye and Witt [27] both obtained a positive relationship between perceptions of support and job performance. Field studies by Cropanzano et al. [26] and Wayne et al. [9] both found that perceived support is negatively correlated with turnover intentions. Similarly, Lynch et al. [22] determined that absenteeism is lower when a company is perceived as supportive $[28,29]$.

There are three reasons for which job performance is supporting a high level of perceived organizational support. First, perceived organizational support is providing many chances of success to his employees and providing the fewer chances of risk in the organization to his employees, therefore, they are obtaining the high level of trust and organizational support. Second, The POS providing that kind responsibility which they are required to the organization. Third, from the high level of POS, the organization can receive his require expectations. From the recent studies arguments, we are supposed that there a positive relationship between POS and job performance [30]. $\mathrm{OCB}$

H3a: Perceived organizational support has a positive relation with

H3b: Perceived organizational support has a positive relationship with job performance.

\section{POS mediates relationship between JIS, OCB and job performance}

Using social exchange theory (SET) Perceived organizational support shows employees' believes of contribution and welfare from the organization, their donation and cares about their well-being [5]. In any organization where POS and OCB are positively related. Although this in the research field of job insecurity, to our knowledge, just one study has considered POS as a mediator between quantitative job insecurity and some attitudinal outcomes, showing that high levels of quantitative job insecurity lead individuals to review their existing support with the organization and adjust their work attitudes. Following these results, we assumed that the effects of qualitative job insecurity on behavioral outcomes may be the same. Cropanzano et al. [26], Nye and Witt [27] both obtained a positive relationship between perceptions of support and job performance. Field studies by Cropanzano et al. [26] and Wayne et al. [9] both found that perceived support is negatively correlated with turnover intentions. Similarly, Eisenberger et al. [17] determined that absenteeism is lower when a company is perceived as supportive [31].

As a matter of fact, high-qualitative job insecurity can reduce the sense relation to a group (according to SET), leading to decrease in job performance and OCB (according to SET). The fair policies and procedures strengthen employee beliefs that they will be rewarded for their efforts to help the organization while receiving benefits from the organization would signal to an employee that $s /$ he is valued. If the organization is not providing the fair policy then its result is opposite direction toward employee performance. The characteristics of organizational citizenship behavior are to share knowledge, to create a feeling of responsibilities of the organization. The past studies arguments show that there are negative relation between JIS and OCB But if POS are applying as mediator, still POS will not take a positive effect between these two, because employee priority are ego, promotion, and incentive, if employee is not receiving these incentive than employee is not satisfied results are bad performance [32]. The past arguments have shown that perceived organizational support can push the employees' responsibilities to take an organizational objective [17]. Using social exchange theory (SET) Perceived organizational support showing employees' global trust related to the organization management think and take about their good well [5]. The relationship between job insecurity and in-role behaviors, Chirumbolo and Areni [3] found that qualitative job insecurity, as well as quantitative job insecurity, decrease job performance. To our knowledge, just one recent study investigated the relationship between qualitative job insecurity and $\mathrm{OCB}$, showing a negative relationship. If any organization which offering the perceived organizational support then the employee's performance will be automatically positive. The employee's priority is security, ego, and basic needs, these all are direct effects on the performance and behavior of employees towards the organization, not need any external support from the environment.

The evidence from the past studies POS playing mediates role positive or negative relationship between job insecurity and $\mathrm{OCB}$, and also positive or negative employee job performance. 
Citation: Khan RU, Ghufran H (2018) The Mediating Role of Perceived Organizational Support between Qualitative Job Insecurity, Organizational Citizenship Behavior and Job Performance. J Entrepren Organiz Manag 7: 228. doi: 10.4172/2169-026X.1000228

Page 4 of 7

H4a: POS mediates the effect of qualitative job insecurity on OCB.

H4b: POS mediates the effect of qualitative job insecurity on JP (Figure 1).

\section{Methodology}

\section{Sample and data}

We collected data from hoteling sector Islamabad and Rawalpindi in Pakistan. We have distributed questioners through e-mail and by hand and covering letter also attaché with each questionnaire. Specifying that the participants had to be an employee of temporary or permanent, anonymity was guaranteed and participation was voluntary. The paper and pencil sent to each organization and requested to deliver them in two months. We have distributed 475 questioners in Islamabad and Rawalpindi in hoteling sector. But we only receive 437 fill questionnaires. In these there are only 387 questionnaires are valuable which we use for analysis. In this data, there are $192 \mathrm{men}$ and 195 women. And the response rate is 81 percent. In these respondents, 30 percent was from 20 to 25 and 40 percent was from 30 to 35 and 30 percent was from 40 to 50 . In these respondents, 40 percent was working in private sector but remaining in the government sector. And 67 percent respondents were married and 33 percent were unmarried. With regards to occupational status, 52.9 percent had a full-time job and about 30 percent reported having a permanent contract, whereas about 17.1 percent had a temporary job (Table 1).

\section{Measures}

Qualitative job insecurity: QJI was measured through the sixteen item scales produced by. One sample item of job insecurity in these scales is "A job in which you can tell how well you are doing as you do it" the Cronbach's Alpha reliability of this scale was .658\%. And the respondents are shown his expression through with the statements on a Likert scale from 1 strongly disagree to 5 strongly agree.

Perceived organizational support: POS was assessed with the six-item scales [5]. This measures how individuals view themselves in terms of their membership in a specific organization. One sample of these of POS is "The Company's recognition and reward programs incent outstanding performance." the Cronbach's Alpha reliability of this scale was $.604 \%$. And the respondent's Participants express his willing against the every with the statements on a Likert scale from 1 strongly disagree to 5 strongly agree.

Organizational citizenship behavior: OCB was measured through the twenty-item scales produced by Maharma. One sample item of this OCB is "I make sure to prevent problems before it occurs" the Cronbach's Alpha reliability of this scale was .662\%. Participants were asked to express their own desire with the statements on a Likert scale from 1 strongly disagree to 5 strongly agree.

Job performance: JP was measured through the seven-item scales produced. One sample item of job performance is "Fulfills responsibilities specified in the job description." the Cronbach's Alpha

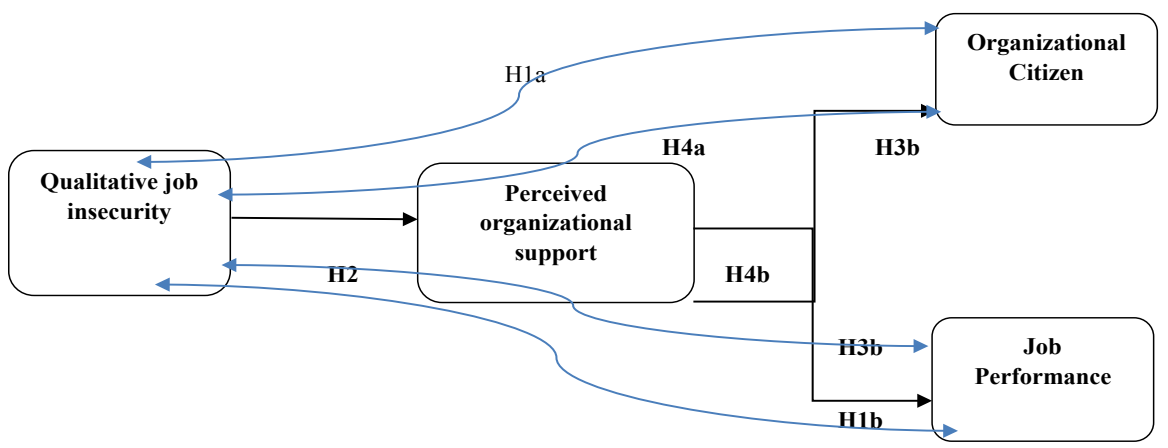

Figure 1: Conceptual framework.

\begin{tabular}{|c|c|c|c|c|c|}
\hline & Frequency & Percent & Valid Percent & Cumulative Percent & Total \\
\hline \multicolumn{6}{|l|}{ Gender } \\
\hline Male & 192 & 49.6 & 49.6 & 49.6 & \multirow[t]{2}{*}{387} \\
\hline Female & 195 & 50.4 & 50.4 & 100 & \\
\hline \multicolumn{6}{|l|}{ Marital Status } \\
\hline Single & 259 & 66.9 & 66.9 & 66.9 & \multirow[t]{2}{*}{387} \\
\hline married & 128 & 33.1 & 33.1 & 100 & \\
\hline \multicolumn{6}{|l|}{ Position } \\
\hline Supervisor & 63 & 16.3 & 16.3 & 16.3 & \multirow[t]{4}{*}{387} \\
\hline Maintenance & 132 & 34.1 & 34.1 & 50.4 & \\
\hline C. Service & 64 & 16.5 & 16.5 & 66.9 & \\
\hline Clerical & 128 & 33.1 & 33.1 & 100 & \\
\hline \multicolumn{6}{|l|}{ Experience } \\
\hline $0-5$ & 178 & 46 & 46 & 46 & \multirow[t]{4}{*}{387} \\
\hline 10-May & 185 & 47.8 & 47.8 & 93.8 & \\
\hline $21-30$ & 12 & 3.1 & 3.1 & 96.9 & \\
\hline Over 30 & 12 & 3.1 & 3.1 & 100 & \\
\hline
\end{tabular}

Table 1: Demographic result. 
Citation: Khan RU, Ghufran H (2018) The Mediating Role of Perceived Organizational Support between Qualitative Job Insecurity, Organizational Citizenship Behavior and Job Performance. J Entrepren Organiz Manag 7: 228. doi: 10.4172/2169-026X.1000228

Page 5 of 7

reliability of this scale was $.695 \%$. The respondent's participants express their desire about each scale on a Likert scale from 1 strongly disagrees to 5 strongly agree.

\section{Control variable}

We use age, gender, and experience during the regression.

\section{Result}

Table 2 Shows the descriptive statistics, and estimates of reliability (co-efficient $\alpha$ ) for all measures. The results represents that there are positive, negative relationship between the main effect hypotheses.

As expected, qualitative job insecurity was negatively related to OCB, job performance and POS, supporting H1a-H2. Moreover, POS was positively related to OCB and job performance, supporting $\mathrm{H} 3 \mathrm{a}-\mathrm{H} 3 \mathrm{~b}$. From our regression result shows that there a negative relationship between organizational citizenship behaviors and qualitative job insecurity, $\beta=-.022$ which shows the negative and significant relationship between these two variables. Therefore our study supporting these hypotheses due to the current results. The regression result shows that there a negative relationship between job performance and qualitative job insecurity $\beta=-.03^{\star *}$ which shows the negative and significant relationship between these two variables. Therefore our study supporting these hypotheses due to the current results. Regression result shows that there a positive relationship between perceived organizational citizenship behavior and organization citizenship behaviors, where $\mathrm{R} 2=.33$ and $\beta=.44^{*}$ which shows there are positive and strong significant where $\mathrm{p}<.05$. Therefore our study supporting these hypotheses due to the current results. Regression result shows that there is a positive relationship between perceived organizational support and job performance, where $\mathrm{R} 2=.52$ and $\beta=.29^{*}$ which shows positive and significant where $\mathrm{p}<.05$ relation between JP and OCB these two variables. Therefore our study supporting these hypotheses due to the current results.

According to SET, POS has a positive relationship with OCB and job performance. Therefore, the employees that share their objective with an organizational objective will perform their job best, from my research results highlighting the important role played by POS in the achievement of job performance. And qualitative job insecurity has negative relationship with OCB because $\beta=-0.2^{\star}$ and $p<.05$. Finally, POS fully playing the role mediator the effects of qualitative job insecurity on job performance. But in other words, qualitative job insecurity decreases the relationship between OCB and job performance only because it reduces effects of POS which directly affects behavioral outcomes (Table 3 ).

\section{Discussion}

Due to the global financial crisis and to the increase of flexible employment contract [1], currently the topic of job insecurity and its significances seems very applicable. As showing by Stynen, most interest within the job insecurity literature has been on understanding the Significance of quantitative job insecurity, while the few studies about qualitative job security have focused on its effects of well-being and organizational attitudes and behaviors. Therefore, research is needed with a specific focus upon the significances of qualitative job insecurity that could affect the employees' OCB and performance and subsequently reduce organizational effectiveness $[15,16]$. Concerning this, our results showed that qualitative job insecurity was negatively related to OCB and job performance. Therefore, in line, employees hesitant about their career and their organizational development will perform their job less effectively. Furthermore, they will also reduce positive behaviors towards colleagues and organizations, because qualitative job insecurity increases employees' competition. In line with SET, qualitative job insecurity was also negatively related to POS, i.e., employees with high worry about work conditions tended to identify less with organization. According to SIT, POS was positively related to OCB and job performance [26,27]. Therefore, employees that share their aims with organizational aims will perform their job better, highlighting the important role played by POS in achievement of inrole and extra-role performance [33].

\begin{tabular}{|c|c|c|c|c|c|c|}
\hline & Mean & SD & Job Insecurity & $\begin{array}{l}\text { Perceived organizational } \\
\text { support }\end{array}$ & $\begin{array}{c}\text { Organization citizen } \\
\text { behavior }\end{array}$ & Job performance \\
\hline Job Insecurity & 25.18 & 1.98 & $(0.66)$ & - & - & -- \\
\hline $\begin{array}{c}\text { Perceived Organizational } \\
\text { support }\end{array}$ & 12.75 & 1.15 & $-0.30^{*}$ & $(0.61)$ & - & - \\
\hline Organization citizen behavior & 20.63 & 1.81 & $-0.29^{*}$ & $0.85^{*}$ & $(0.67)$ & \\
\hline Job performance & 14.87 & 1.35 & $0.16^{*}$ & $0.83^{*}$ & $0.76^{*}$ & $(0.7)$ \\
\hline
\end{tabular}

Sample $=387, \alpha$ reliability of each scale are shown, ${ }^{*} p<.05$

Table 2: Descriptive statistics and correlations.

\begin{tabular}{|c|c|c|c|c|c|c|}
\hline & \multicolumn{3}{|c|}{ Job Performance } & \multicolumn{3}{|c|}{ Organization citizen behavior } \\
\hline & $\beta$ & $\mathbf{R}^{2}$ & $\Delta \mathbf{P}^{2}$ & $\beta$ & $\mathbf{R}^{2}$ & $\Delta \mathbf{P}^{2}$ \\
\hline \multicolumn{7}{|l|}{ Step 1: Control Variable } \\
\hline Age & $.09^{*}$ & & & $0.33^{* *}$ & & \\
\hline Gender & $.02^{*}$ & & & $0.10^{*}$ & & \\
\hline Experience & $.07^{* *}$ & 0.37 & & $0.28^{*}$ & 0.26 & \\
\hline \multicolumn{7}{|l|}{ Step 2} \\
\hline Age & $0.09^{* *}$ & & & $0.36^{*}$ & & \\
\hline Gender & $0.02^{*}$ & & & $0.11^{\star *}$ & & \\
\hline Experience & $0.02^{*}$ & & & $0.32^{*}$ & & \\
\hline Job insecurity & $-0.03^{* *}$ & & & $-0.02^{* *}$ & & \\
\hline $\begin{array}{c}\text { Perceived organizational } \\
\text { support }\end{array}$ & $0.29^{* *}$ & 0.52 & 0.15 & $0.44^{* *}$ & 0.32 & 0.06 \\
\hline
\end{tabular}

Table 3: Regression model. 
Citation: Khan RU, Ghufran H (2018) The Mediating Role of Perceived Organizational Support between Qualitative Job Insecurity, Organizational Citizenship Behavior and Job Performance. J Entrepren Organiz Manag 7: 228. doi: 10.4172/2169-026X.1000228

Page 6 of 7

Finally, POS fully mediated the effects of qualitative job insecurity on in-role and extra-role performance because we discuss it during partial regression model where their relation was significance. This means that qualitative job insecurity does not directly affect behavioral outcomes, but its effect passes through POS; in other words, qualitative job insecurity reduces OCB and job performance only because it reduces POS which directly affects behavioral outcomes. In sum, the present study helps to clarify the relationship among qualitative job insecurity and in-role and extra-role performance, revealing key role of POS with some important theoretical and practical implications [34].

\section{Theoretical Implication}

First, in the current study some arguments supporting the SET which results shows that there are negative relation between qualitative job insecurity and job performance [13]. For example, employee receives rewards like careers opportunities, incentives or package improvement than employee feels satisfaction from these. Second, the current study results shows that POS has a positive relationship with both on voluntary and unceremonious behaviors, such as OCB, and on agreement ally required behaviors. Thus, when any employee which is supported by the organization then they have the positive towards employees. It adding the context to the documentation on job insecurity and job performance. Third, in the past many studies showing that there are negative relationship of job insecurity on the OCB and job performance, But the present study clearly mention the relationship for the first time, POS using as mediator.

\section{Conclusion}

In this current study we are trying to understand the effects of that how qualitative job insecurity may reduce job performance and applying to test the mediating role of POS in this relationship. The results supported our hypotheses because qualitative job insecurity had a significant negative effect on POS and after that latter fully mediated the effect of qualitative job insecurity on $\mathrm{OCB}$ and job performance. In this study first time that research are explaining the POS. The present study for the first time considers POS and its human being help structure in a manner to provide a theoretical explanation to behavioral series of qualitative job insecurity.

\section{Practical Implication}

In our present study there are some practical implications. The organization management and practical experience should be adopted to decrease qualitative job insecurity in order to reduce its negative effects on POS. And automatically increase positive behavioral results. The manager is requiring that to reduce the job insecurity which is automatically effect on the POS. For example, organizations should address HRM planning that to issuing new opportunities for employee and promotion which is directly effect on the employee performance for short and long term. The Managers could make a decision that to add the employee on decision making through the company performance will be well. And the HRM manager will be developing of activities through which the employee membership and support are increase. At least when high level of employee is supported through the organization towards the success. And that leads to the goal achieving for the long term.

\section{Limitation and Future Direction}

In this study there are many important limitations that must be discussed. First suggestion for further researcher is to increase the number of respondents. Second we are using only limited area of data, for further expand the data to other sectors.

\section{References}

1. Callea A, Urbini F, Ingusci E, Chirumbolo A (2016) The relationship between contract type and Job satisfaction in a mediated moderation model: The role of job insecurity and psychological Contract violation. Econ Ind Democr 37 399-420.

2. Sverke M, Hellgren J, Naswall K (2002) No security: a meta-analysis and review of job Insecurity and its consequences. J Occup Health Psychol 7: 242-264.

3. Chirumbolo A, Areni A (2010) Job insecurity influence on job performance and mental health: testing the moderating effect of the need for closure. Econ Ind Democr 31: 195-214.

4. Burke RJ, Cooper CL (2000) The organization in crisis: Downsizing, restructuring, and Privatization. Blackwell Publishing.

5. Eisenberger R, Huntington R, Hutchison S, Sowa D (1986) Perceived organizational support. J Appl Psychol 71: 500-507.

6. Eisenberger R (2002) Perceived supervisor support: contribution to perceived organizational support and employee retention. J Appl Psychol 87: 565-573.

7. Greenhalgh L, Rosenblatt Z (1984) Job insecurity: Toward conceptual clarity Acad Manag Rev 9: 438-448.

8. Hellgren J, Sverke M, Isaksson K (1999) A two-dimensional approach to job insecurity: Consequences for employee attitudes and well-being. Eur $\mathrm{J}$ Work Organ Psy 8: 179-195.

9. Wayne SJ, Shore LM, Liden RC (1997) Perceived organizational support and leader member exchange: A social exchange perspective. Acad Manag J 40 82-111.

10. Podsakoff PM, MacKenzie SB, Paine JB, Bachrach DG (2000) Organizationa citizenship behaviors: A critical review of the theoretical and empirical literature and suggestions for future research. J Manag 26: 513-563.

11. Wang WJ, Li JW (2007) The research on influence of perceived organization support upon organizational citizenship behavior. Chinese Business and Market 8: 53-55

12. Rotundo M, Sackett PR (2002) The relative importance of task, citizenship, and Counterproductive performance to global ratings of job performance: a policycapturing approach. J Appl Psychol 87: 66-80.

13. Feather NT, Rauter KA (2004) Organizational citizenship behaviors in relation to job status, job Insecurity, organizational commitment and identification, job satisfaction and work values. J Occup Organ Psychol 77: 81-94.

14. Van Dyne L, Ang S (1998) Organizational citizenship behavior of contingent workers in Singapore. Acad Manag J 41: 692-703.

15. Cavanaugh MA, Noe RA (1999) Antecedents and consequences of relational components of the new psychological contract. J Organ Behav 20: 323-340.

16. Restubog SLD, Hornsey MJ, Bordia P, Esposo SR (2008) Effects of psychological contract breach on organizational citizenship behaviour: Insights from the group value model. J Manag Stud 45: 1377-1400.

17. Eisenberger R, Armeli S, Rexwinkel B, Lynch PD, Rhoades L (2001) Reciprocation of perceived organizational support. J Appl Psychol 86: 42-51.

18. Miao RT, Sun JM, Liu J (2012) The effects of organizational perceived support and organizational justice on work attitude and organizational citizenship behaviors. J Bus Econ 9: 29-39.

19. Wei JR (2010) Research on the relationship between organizational support to knowledge employees and organizational citizenship behavior at high-tech enterprises. Soft Science 24: 109-111.

20. Settoon PR, Bennett N, Robert CL (1996) Social Exchange in Organizations: Perceived Organizational Support, Leader-Member Exchange, and Employee Reciprocity. J Appl Psychol 81: 219-227.

21. Kaufman JD, Christina L, Stamper E, Tesluk PE (2001) Do Supportive Organizations Make for Good Corporate Citizens? J Manag Iss 13: 436-449.

22. Lynch PD, Eisenberger R, Armeli S (1999) Perceived Organizational Support Inferior Versus Superior Performance byWary Employees. J Appl Psychol 84 467-483. 
Citation: Khan RU, Ghufran H (2018) The Mediating Role of Perceived Organizational Support between Qualitative Job Insecurity, Organizational Citizenship Behavior and Job Performance. J Entrepren Organiz Manag 7: 228. doi: 10.4172/2169-026X.1000228

23. Hochwarter WA, Witt LA, Treadway DC, Ferris GA (2006) Interaction of organizational support and social skill on job performance. J Appl Psychol 91: 482-489.

24. Erdogan B, Kraimer ML, Liden RC (2004) Work value congruence and intrinsic career success: The compensatory roles of leader-member exchange and perceived organizational support. J Pers Psycho 57: 305-332.

25. Oh JE, Rutherford BN, Parki JK (2014) The interplay of salesperson's job performance and satisfaction in the financial services industry. J Financ Serv Market 19: 104-117.

26. Cropanzano R, Howes JC, Grandey AA, Toth P (1997) The relationship of Organizational Politics and support to work behaviors, attitudes, and stresses. J Organ Behav 18: 159-180.

27. Nye LG, Witt LA (1993) Dimensionality and construct validity of the Perceptions of Politics Scale (POPS). Educ Psychol Meas 53: 821-829.

28. Ben-Porath SR (2009) Citizenship under fire: Democratic education in times of conflict. Princeton University Press.
29. Ling WQ, Yang HJ, Fang LL (2006) Perceived organizational support (POS) of the employees. Acta Psychologica Sinica 38: 281-287.

30. Luthans BC, Sommer SM (1999) The impact of downsizing on workplace attitudes. Group Organ Manag 24: 46-70.

31. Masterson SS, Lewis K, Goldman BM, Taylor MS (2000) Integrating Justice and Social Exchange: The Differing Effects of Fair Procedures and Treatments on Work Relationships. Acad Manag J 43: 738-748.

32. Mone MA (1994) Relationships between self-concepts, aspirations, emotional responses, and intent to leave a downsizing organization. Human Resource Management 33: 281-298.

33. Razavi S, Sanagooe G, Shirazi MM, Aj Asaran M (2017) Role of Moral Intelligence in Predicting Job Performance of Female. JAMET 13: 207-212.

34. TabibNejad N (2003) The relationship between leadership styles and organizationalcommitment, and job performance subordinates, according to the domination of subordinates in the sugar factory Debal Khazaei, quarterly monitoring $4: 81-105$ 